Original article

\title{
Lincomycin hydrochloride for the control of American foulbrood disease of honey bees*
}

\author{
Mark F. Feldlaufer ${ }^{\text {a*** }}$ Jeffery S. Pettis $^{\mathrm{a}}$, Jan P. Kochansky ${ }^{\mathrm{a}}$, \\ Grant STILES ${ }^{b}$ \\ a USDA, Agricultural Research Service, Bee Research Laboratory, \\ Bldg. 476, BARC-East, Beltsville MD 20705, USA \\ b NJ Depart. of Agriculture, Division of Plant Industry, CN330, Trenton NJ 08625, USA
}

(Received 29 December 2000; revised 16 July 2001; accepted 30 July 2001)

\begin{abstract}
The antibiotic lincomycin hydrochloride was evaluated for toxicity to larval and adult honey bees and for efficacy in controlling American foulbrood disease (AFB). Results of toxicity studies involving nine applications of lincomycin (200-, 600-, or $1000 \mathrm{mg}$ active ingredient per application) as a dust in confectioners sugar revealed no significant differences in mortality among any of the treatment groups for either adults or larvae, when compared to untreated or sugar-treated controls. In field efficacy studies, 18 colonies with existing oxytetracycline-resistant AFB were dusted three times, one week apart, with either 100-, 200-, or $400 \mathrm{mg}$ lincomycin (in $20 \mathrm{~g}$ confectioners sugar). Forty- five days after the third treatment, no visible signs of AFB could be found, regardless of the initial severity of disease or the dose applied.
\end{abstract}

lincomycin / toxicity / American foulbrood / antibiotic / control

\section{INTRODUCTION}

American foulbrood disease (AFB) is a highly contagious disease of honey bee brood caused by the bacterium Paenibacillus larvae subsp. larvae. The disease is spread in a number of ways including drifting bees and the interchange of contaminated bee equipment between colonies. The disease has been controlled either by the destruction of infected colonies by burning, or by the use of antibiotics. Oxytetracycline

* Disclaimer: "Mention of trade names or commercial products in this article is solely for the purpose of providing specific information and does not imply recommendation or endorsement by the US Department of Agriculture".

** Correspondence and reprints

E-mail: feldlaum@ba.ars.usda.gov 
hydrochloride $\left(\mathrm{OTC}=\right.$ Terramycin $\left.^{\circledR}\right)$ remains the only approved drug treatment available in the United States for the prevention and control of AFB (see Shimanuki, 1997). As late as 1993 , no difference in sensitivity to OTC could be detected in laboratory disk diffusion assays using $P$. larvae spores collected prior to and after the introduction of OTC (Shimanuki and Knox, 1994). However, in 1996 reports from Argentina indicated possible drug resistance (Alippi, 1996). Since those initial findings, foulbrood resistant to OTC treatment has been documented in the literature (Alippi, 2000; Miyagi et al., 2000) and by our diagnostic service in 24 states (unpublished data).

Laboratory screening of antibiotics indicated that the lincosaminide lincomycin effectively inhibited the growth of OTCresistant $P$. larvae (Kochansky et al., 2001). We therefore undertook a study to determine the safety of lincomycin to immature and adult honey bees, and the efficacy of lincomycin against OTC-resistant American foulbrood under field conditions.

\section{MATERIALS AND METHODS}

\subsection{Antibiotic and doses}

Lincomycin hydrochloride was purchased commercially as Lincomix ${ }^{\circledR}$ Soluble Powder (Pharmacia \& Upjohn, Kalamazoo MI). All antibiotic treatments were prepared as a dust in $20 \mathrm{~g}$ confectioners sugar, and applied across the top bars of frames in the brood chamber. We chose $200 \mathrm{mg}$ lincomycin applied three times, one week apart, as our targeted dose and treatment regime, respectively. The choice of $200 \mathrm{mg}$ lincomycin was based on microbiological assay in which comparable zones of inhibition were observed between lincomycin and OTC (Kochansky et al., 2001). The treatment regime is similar to that currently used for OTC dust, and results in a total colony exposure of $600 \mathrm{mg}$ antibiotic.

\subsection{Target animal safety}

\subsubsection{Colonies and treatments}

Twenty queenright colonies with no visible signs of disease and containing no surplus honey were maintained in 2-story, 10-frame Langstroth hives in Beltsville MD. We chose $200 \mathrm{mg}$ lincomycin as our targeted dose, but also examined higher doses $(600 \mathrm{mg}=3 \mathrm{X} ; 1000 \mathrm{mg}=5 \mathrm{X})$ for toxicity to bees to fulfill FDA requirements for target animal safety. Therefore, colonies were randomly subdivided into five treatment groups consisting of (1) untreated control (no sugar; no drug); (2) sugar treated control (no drug); (3) $200 \mathrm{mg}$ lincomycin hydrochloride; (4) $600 \mathrm{mg}$ lincomycin hydrochloride; and (5) $1000 \mathrm{mg}$ lincomycin hydrochloride. Each treated group (2-5) received an application every seven days, until a total of nine applications were made. This represents three times what we would consider a normal treatment regime, but was included to meet Food and Drug Administration (FDA) requirements for target animal safety. The study began on July 20, 2000 and was terminated 68 days later on September 25, 2000 .

\subsubsection{Monitoring adult mortality}

Test colonies were maintained on a concrete pad, and an area $\left(0.25 \mathrm{~m}^{2}\right)$ at each colony entrance was marked with indelible crayon. Dead adult bees in the marked area were recorded one-day, four-days and sevendays after each treatment for the duration of the study. After each recording, dead bees were removed from the marked area. During the study, the presence of immature brood was used as an indication of a viable laying queen. At the end of the study, the queen was visually observed.

\subsubsection{Monitoring larval mortality}

Two areas (100 cells each; approx. $25 \mathrm{~cm}^{2}$ each) on a frame containing larval bees were marked in every colony immediately prior to 
the first, fourth and eighth treatment. The number of larvae in each area was recorded and seven days post-treatment, the number of capped cells in each area was used as a measure of toxicity to larval bees. Eighteen days post-treatment, marked areas were inspected for emerging/emerged brood. Due to a dearth of pollen and nectar, all colonies were fed four liters sugar syrup (sugar:water; 2:1) and were given a $300 \mathrm{~g}$ pollen patty (pollen:sugar; 4:1) two weeks prior to the eighth treatment, to ensure immature brood for the last portion of the larval toxicity study.

\subsubsection{Data analysis}

\subsubsection{Adults}

Counts of dead adult bees (Y) were transformed using $\log (\mathrm{Y}+1)$ to remove the dependency of the variance on the mean. ANOVA on the transformed counts were conducted using Proc Mixed (SAS Institute, 1997). Our independent variables were treatment (200, 600, $1000 \mathrm{mg}$ lincomycin; untreated; and sugar-treated), number of days following treatment (one, four, seven), and time of year (seasonal). For these analyses, various repeated measures covariance structures were estimated, with colony as the repeated measure. A compound symmetric covariance structure was preferred on both AIC and BIC measures (see SAS Institute, 1997). Power analysis was performed using the repeated measures module of the Pass 2000 software (Pass, 2000).

\subsubsection{Larvae}

The proportions of larvae sealed seven days post-treatment relative to the number of initial larvae marked were transformed using a standard arcsine transformation $\left(\right.$ sine $^{-1}$ (square root of Y)). An ANOVA of the transformed proportions was run using Proc Mixed (SAS, 1997). Our independent variables were treatment $(200,600,1000 \mathrm{mg}$ lincomycin; untreated; and sugar-treated) and time of year (seasonal, i.e. beginning, middle and end of study). As with adults, we used a repeated measures compound symmetric covariance structure, with colony as the repeated measure.

\subsection{Field efficacy}

\subsubsection{Colonies and treatments}

A quarantine apiary was established in Pennsville NJ, consisting of 19 colonies with visible AFB. These colonies were previously treated by the owner with Terramycin ${ }^{\circledR}$ patties earlier in the year, but remained resistant to treatment. Comb samples from all colonies were subsequently tested in Beltsville MD by disk diffusion and indicated resistant $P$. larvae.

Colonies were scored as to their degree of disease similar to Hitchcock et al. (1970). The disease was considered "light", if fewer than 10 diseased cells per colony were found; "moderate", if 11-100 diseased cells per colony were found; and "severe", if greater than 100 diseased cells were found per colony. Based on this scoring system, four colonies were considered "light", six colonies "moderate", and nine, "severe". Colonies were dusted with lincomycin in $20 \mathrm{~g}$ confectioners sugar three times, one week apart, in doses of either $100 \mathrm{mg}$, $200 \mathrm{mg}$ or $400 \mathrm{mg}$ active ingredient per application. This represents the targeted dose (200 mg), and additional doses (one-half the targeted dose and twice the targeted dose) required by FDA for antibiotic efficacy studies. Table I presents the individual doses administered to the colonies in our study. Colonies were re-scored with regard to their disease rating prior to the third treatment and subsequently evaluated 45-days after the third treatment. Colonies in which there were no visible signs of new disease at this time were considered recovered.

\subsubsection{Data analysis}

The number of colonies rated as either "diseased" or "recovered" (no disease) at 
Table I. Dosages of lincomycin applied to field colonies with OTC-resistant AFB ${ }^{1}$.

\begin{tabular}{llccc}
\hline \multirow{2}{*}{ Colony disease rating } & & \multicolumn{3}{c}{ Number of colonies receiving } \\
\cline { 3 - 5 } & $\mathrm{N}$ & $100 \mathrm{mg}$ & $200 \mathrm{mg}$ & $400 \mathrm{mg}$ \\
\hline Light & 4 & 1 & 3 & 0 \\
Moderate & 6 & 2 & 3 & 1 \\
Severe & 9 & 1 & 3 & 5 \\
\hline
\end{tabular}

${ }^{1}$ Colonies were treated with either 100-, 200-, or 400-mg lincomycin as a dust in $20 \mathrm{~g}$ confectioners sugar, three times, one week apart.

${ }^{2}$ Colonies were rated according to Hitchcock et al. (1970). See "Materials and Methods" (Sect. 2.3.1).

the beginning and end of the study was analyzed using a $2 \times 2$ contingency table and chi-square.

\section{RESULTS}

\subsection{Target animal safety}

The average mortality of adult and larval honey bees treated with various doses of lincomycin in a sugar dust is summarized in Table II. ANOVA of the individual transformed data (not shown) revealed no differences in mortality among any of the treatment groups for either adults $(p>0.15)$ or larvae $(p>0.45)$. For adults, there was no significant difference in mortality $(p>0.09)$ on the number of days following treatment (one, four, or seven days after treatment). While there was a significant seasonal effect (counts of dead bees increased with time over the course of the study) for both adults $(p<0.0001)$ and larvae $(p<0.0001)$, this was not attributable to the treatments, as there were no significant interaction effects (all $p>0.05$ ). The power analysis of the treatment effect for adults was estimated at $97 \%$. Due to the smaller larval sample size, the power on the test of treatment effects for larvae was only $60 \%$. However, the

Table II. Average mortality of adult and larval honey bees (mean \pm SE) from colonies treated weekly for nine weeks with varying doses of lincomycin.

\begin{tabular}{|c|c|c|c|c|c|}
\hline & \multicolumn{5}{|c|}{ Treatment $^{1}$} \\
\hline & Untreated & Sugar & $200 \mathrm{mg}$ & $600 \mathrm{mg}$ & $1000 \mathrm{mg}$ \\
\hline $\begin{array}{l}\text { Average No. } \\
\text { dead bees }{ }^{2}\end{array}$ & $3.1 \pm 0.3$ & $2.8 \pm 0.4$ & $4.7 \pm 0.5$ & $4.1 \pm 0.5$ & $5.7 \pm 0.7$ \\
\hline $\begin{array}{l}\% \text { Larval }^{3} \\
\text { mortality }\end{array}$ & $6.3 \pm 0.8$ & $9.5 \pm 1.2$ & $6.7 \pm 1.5$ & $6.6 \pm 1.1$ & $6.7 \pm 0.9$ \\
\hline
\end{tabular}

${ }^{1}$ Antibiotic treatment was as a dust in $20 \mathrm{~g}$ confectioners sugar applied across the top bars of frames in the brood chamber.

${ }^{2}$ Dead adult bees counts were recorded three times a week from a marked area $\left(0.25 \mathrm{~m}^{2}\right)$ in front of each hive ( $n=27$ observations/colony; 4 colonies/treatment).

3 The proportions of larvae sealed seven days post-treatment relative to the number of initial larvae present in a 100 -cell area were recorded. Larval mortality data was calculated by subtracting this proportion from " 1 " and multiplying by "100" ( $n=6$ observations/colony; 4 colonies/treatment). 
treatment $p$-value is so large $(p>0.45)$, it is reasonable to conclude there is no significant treatment effect. All inspections for emerged or emerging bees eighteen days post treatment in the larval portion of this study revealed no abnormalities.

No queens were superseded during the study as all marked queens were accounted for when the study was terminated.

\subsection{Field efficacy}

The ability of lincomycin to control AFB in colonies infected with OTC-resistant $P$. larvae is summarized in Table III. Nineteen colonies with varying degrees of AFB were dusted with different doses of lincomycin. One colony with "severe" disease was found to be queenless one week into the study and was removed. Of the eighteen remaining colonies, most showed marked signs of improvement after two treatments. At this rating time, only two colonies, one scored "severe", the other scored "moderate", remained in their initial groups. All other colonies improved their score. None of the eighteen colonies showed any visible signs of disease when examined 45- days after the last treatment, regardless of the dose of lincomycin received $(p<0.001$; chi-square).

\section{DISCUSSION}

While different cultural methods have been proposed for controlling AFB (see Shimanuki, 1997; Van Eaton, 2000), as well as breeding hygienic bees that diligently remove AFB-infected larvae (Spivak and Gilliam, 1998; Spivak and Reuter, 1998), antibiotics still remain a valuable tool. We have shown that the lincosaminide antibiotic lincomycin, when applied to honey bee colonies as a dust in confectioners sugar, is effective in controlling OTC-resistant AFB. Colonies with existing AFB and resistant to treatment with Terramycin ${ }^{\circledR}$ were shown to be free of any disease 45 days after a third dusting with lincomycin. Furthermore, we demonstrated that lincomycin dusts are not toxic to either adult or larval honey bees. This was evident when three- and five-times the envisioned dose was applied to colonies for a period of nine weeks, three-times the envisioned treatment regime. The macrolide antibiotic tylosin also has been shown to be relatively non-toxic to bees and effective in controlling AFB (Hitchcock et al., 1970;

Table III. Efficacy of lincomycin in controlling oxytetracycline-resistant AFB ${ }^{1}$.

\begin{tabular}{lccc}
\hline & \multicolumn{3}{c}{ Number of colonies } \\
\cline { 2 - 4 } Colony disease rating & & $\begin{array}{c}\text { After two } \\
\text { Prior to } \\
\text { treatment }\end{array}$ & $\begin{array}{c}\text { 45 days after } \\
\text { third treatment }\end{array}$ \\
\hline Light & 4 & 3 & 0 \\
Moderate & 6 & 4 & 0 \\
Severe & 9 & $1^{3}$ & 0 \\
Recovered & - & -5 & 18
\end{tabular}

${ }^{1}$ Colonies were treated with either 100-, 200, or 400-mg lincomycin as a dust in $20 \mathrm{~g}$ confectioners sugar, three times, one week apart. Table does not distinguish between the levels of treatment.

2 Colonies were rated according to Hitchcock et al. (1970). See "Materials and Methods" (Sect. 2.3.1).

${ }^{3}$ A second colony rated "severe" was found to be queenless and was removed from the study.

${ }^{4}$ Colonies with no visible sign of AFB 45 days after the third treatment were considered "recovered".

5 Ten colonies showed no sign of AFB, but did not fit our definition of "recovered", since the third treatment had not been applied. 
Peng et al., 1996), including OTC-resistant strains (Kochansky et al., 2001). Both lincomycin and tylosin should play a valuable role in the control of OTC-resistant AFB, as they are structurally dissimilar to each other and to oxytetracycline, thereby reducing the possibility of cross resistance.

\section{ACKNOWLEDGEMENTS}

We thank M. Kramer, Biometrical Consulting Services, Beltsville MD for statistical analyses. We also thank B. Harvey, A. Park, D. Vincent, and K. Wilzer for valuable technical assistance.

Résumé - L'hydrochlorure de lincomycine comme moyen de lutte contre la loque américaine. La loque américaine (AFB) est une maladie hautement contagieuse du couvain d'abeilles (Apis mellifera L.) causée parla bactérie Paenibacillus larvae subsp. larvae. L'hydrochlorure d'oxytetracycline $\left(\mathrm{OTC}=\right.$ Terramycine $\left.^{\circledR}\right)$ reste le seul traitement médicamenteux autorisé aux États-Unis pour la prévention et la lutte contre l'AFB. Pourtant des cas de loque américaine résistante à l'OTC ont été récemment signalés. Le criblage des antibiotiques au laboratoire a montré que le lincosaminide lyncomycine inhibait efficacement la croissance de $P$. larvae résistant à l'OTC. Une étude a été entreprise pour déterminer la sécurité de la lincomycine vis-à-vis des abeilles immatures et adultes et l'efficacité en conditions naturelles de la lincomycine contre la loque américaine résistante à l'OTC. Vingt colonies avec reine ne présentant pas de signes de maladie et ne contenant pas de surplus de miel ont été maintenues à Beltsville, Maryland. Nous avons choisi $200 \mathrm{mg}$ de lincomycine comme dose ciblée mais avons également examiné des doses plus fortes de toxicité pour les abeilles. Les colonies ont été subdivisées en cinq groupes de traitement : (1) témoin non traité (ni sucre, ni médicament), (2) témoin traité au sucre (pas de médicament), (3)
$200 \mathrm{mg}$ d'hydrochlorure de lincomycine, (4) $500 \mathrm{mg}$ d'hydrochlorure de lincomycine et (5) $1000 \mathrm{mg}$ d'hydrochlorure de lincomycine. Chacun des groupes 2-5 a été traité tous les sept jours et a reçu un total de neuf traitements. Cela représente trois fois ce que nous considérons comme étant un régime normal de traitement. Les abeilles trouvées mortes sur une surface de $0,25 \mathrm{~m}^{2}$ devant la ruche ont été comptées un jour, quatre jours et sept jours après chaque traitement. Pour la mortalité larvaire nous avons délimité dans chaque colonie deux surfaces de 100 cellules chacune (environ $25 \mathrm{~cm}^{2}$ ) sur un rayon contenant des larves d'abeilles juste avant le premier, le quatrième et le huitième traitement. Sept jours après le traitement, la présence de couvain operculé dans chaque zone délimitée a été notée et utilisée comme indication de non toxicité visà-vis des larves. Pour les études d'efficacité, nous avons mis en quarantaine un rucher constitué de colonies présentant des signes patents de loque américaine. Ces colonies avaient été traitées auparavant à la Terramycine ${ }^{\circledR}$, mais étaient restées résistantes au traitement. Les colonies ont été saupoudrées de lincomycine mélangée à $20 \mathrm{~g}$ de sucre trois fois à une semaine d'intervalle aux doses de $100 \mathrm{mg}, 200 \mathrm{mg}$ ou $400 \mathrm{mg}$ de substance active par application. Le degré d'atteinte des colonies a été réévalué avant le troisième traitement puis à nouveau 45 jours après. Les colonies sans signes apparents de nouvelle maladie ont été considérées comme guéries. Le tableau II donne la mortalité moyenne des abeilles adultes et des larves traitées aux différentes doses de lincomycine mélangée à du sucre en poudre. L'ANOVA des données individuelles transformées (non mentionnées) n'a pas montré de différence dans la mortalité entre aucun des divers groupes, que ce soit pour les adultes ou pour les larves. Il n'y a pas eu d'interactions significatives. Le tableau III indique la capacité de la lincomycine à contrôler la loque américaine dans les colonies infectées avec $P$. larvae résistant à l'OTC. 19 colonies atteintes à des degrés 
divers de la maladie ont été saupoudrées avec différentes doses de liconmycine. Une colonie gravement atteinte a été trouvée orpheline une semaine après le début de l'étude et a été éliminée. Des 18 colonies restantes, aucune n'a montré de signes visibles de maladie lorsqu'elles ont été examinées 45 jours après le dernier traitement, quelle que soit la dose de lincomycine reçue. Nous pensons que la lincomycine, appliquée en poudre, est une alternative valable à la Terramycine ${ }^{\circledR}$ pour contrôler la loque américaine.

loque américaine / lutte chimique / lincomycine /antibiotique / toxicité

Zusammenfassung - Lincomycinhydrochlorid zur Bekämpfung der Âmerikanischen Faulbrut bei Honigbienen. Die Amerikanische Faulbrut (AFB) ist eine hoch ansteckende Krankheit der Brut der Honigbienen und wird durch das Bakterium Paenibacillus larvae subsp. larvae verursacht. Oxytetracyclinhydrochlorid $(\mathrm{OTC}=$ Terramycin ${ }^{\circledR}$ ) bleibt das einzige zur Behandlung zugelassene Mittel in den Vereinigten Staaten von Amerika zur Prävention und Behandlung der AFB. Kürzlich wurde aber eine Resistenz der Faulbrut gegen OTC dokumentiert. Beim Screening von Antibiotika im Labor zeigte Lincosaminid Lincomycin eine effektive Hemmung des Wachstums von OTC-resistenten P. larvae. Eine Untersuchung schloss sich an, um die Sicherheit von Lincomycin auf Brut und adulte Honigbienen und die Wirksamkeit von Lincomycin gegen OTC-resistente AFB Stämme zu bestimmen. Zwanzig weiselrichtige Völker ohne erkennbare Anzeichen der Krankheit wurden in Beltsville MD gehalten. Wir wählten $200 \mathrm{mg}$ Lincomycin als unsere Zieldosis, aber nahmen auch höhere Dosen für die Untersuchung der Toxizität für Bienen. Dafür wurden die Völker zufällig in 5 Versuchsgruppen unterteilt, die folgendermaßen behandelt wurden: (1) unbehandelte Kontrolle (kein Zucker, kein
Behandlungsmittel), (2) mit Zucker gefütterte Kontrollen (kein Behandlungsmittel), (3) Behandlung mit $200 \mathrm{mg}$ Lincomycinhydrochlorid, (4) mit 600mg Lincomycinhydrochlorid und (5) mit 1000 mg Lincomycinhydrochlorid. Bei allen behandelten Völkern wurde die Applikation alle 7 Tage wiederholt bis insgesamt 9 Behandlungen durchgeführt waren. Das entspricht dreimal so viel wie wir mit normaler Behandlungsvorschrift erwarten. Tote Bienen wurden auf einer $0,25 \mathrm{~m}^{2}$ markierten Fläche vor jedem Volk bestimmt, und zwar in Abständen von 1 Tag, 4 und 7 Tagen nach jeder Behandlung. Um die Mortalität der Larven zu bestimmen, wurden 2 Brutbereiche (jeweils 100 Zellen, etwa $25 \mathrm{~cm}^{2}$ ) in jedem Volk vor der ersten, der 4 und 8 . Behandlung markiert. Sieben Tage nach der Behandlung wurde das Vorhandensein von verdeckelter Brut in jedem markierten Bereich bestimmt und als Indikation für eine nicht vorkommende Toxizität für die Brut benutzt. Für die Wirksamkeitsstudien wurde ein Quarantäne-Bienenstand mit sichtbaren Symptomen der AFB eingerichtet. Diese Völker waren zuvor mit Terramycin ${ }^{\circledR}$ behandelt worden, hatten aber nicht auf die Behandlung reagiert. Die Völker wurden im Abstand von jeweils 1 Woche 3 mal mit Lincomycin in $20 \mathrm{~g}$ Puderzucker eingestäubt, und zwar mit $100 \mathrm{mg}, 200 \mathrm{mg}$ oder $400 \mathrm{mg}$ der aktiven Substanz pro Behandlung. Die Völker wurden noch einmal vor der 3. Behandlung bewertet und dann noch einmal 45 Tage nach der 3. Behandlung. Völker, die keine sichtbaren Zeichen der Krankheit aufwiesen, wurden als geheilt klassifiziert.

Der mittlere Mortalität von adulten Bienen und der Brut, die mit verschiedenen Dosen Lincomycin in Puderzucker behandelt wurden, sind in Tabelle II zusammengefasst. ANOVA der individuell transformierten Daten (nicht gezeigt) erwies weder bei den Adulten noch bei der Brut Unterschiede in der Mortalität zwischen irgendeiner der Behandlungsgruppen. Auch gab es keine signifikanten Effekte von Interaktionen. Die 
Eignung von Lincomycin zur Behandlung von AFB, die mit OTC-resistenten P. larvae infiziert sind, sind in Tabelle III dargestellt. Neunzehn Völker mit unterschiedlich starkem Befall von AFB waren mit unterschiedlichen Dosen Lincomycin eingestäubt worden. Ein Volk mit ,starkem“ Befall erwies sich eine Woche nach Beginn der Studie als weisellos und wurde entfernt. Von den 18 übrigen Völkern waren bei der Kontrolle nach 45 Tagen keine Zeichen der Krankheit mehr erkennbar, unabhängig von der Lincomycin Dosis. Wir meinen, dass eine Einstäubung mit Lincomycin eine geeignete Alternative zur Behandlung von AFB mit Terramycin ${ }^{\circledR}$ ist.

Lincomycin / Toxizität / AFB-Behandlung

\section{REFERENCES}

Alippi A. (2000) Is Terramycin ${ }^{\circledR}$ losing its effectiveness against AFB, Bee Biz 11, 27-29.

Alippi A.M. (1996) Caracterización de aislamientos de Paenibacillus larvae mediante tipo bioquímico y resistencia a oxitetraciclina, Rev. Arg. Microbiol. 28, 197-203.

Hitchcock J.D., Moffett J.O, Lackett J J., Elliott J R. (1970) Tylosin for control of American foulbrood disease in honey bees, J. Econ. Entomol. 63, 204-207.
Kochansky J.P., Knox D.A., Feldlaufer M.F., Pettis J.S. (2001) Screening alternative antibiotics against oxytetracycline-susceptible and resistant American foulbrood, Apidologie 32, 215-222.

Miyagi T., Peng C.Y.S., Chuang R., Mussen E.C., Spivak M.S., Doi R.H. (2000) Verification of oxytetracycline-resistant American foulbrood pathogen Paenibacillus larvae in the United States, J. Invertebr. Pathol. 75, 95-96.

Pass Users Guide (2000) NCSS, Kaysville, UT.

Peng C.Y.S., Mussen E., Fong A., Cheng P., Wong G., Montague M.A. (1996) Laboratory and field studies on the effects of the antibiotic tylosin on honey bee Apis mellifera L. (Hymenoptera: Apidae) development and prevention of American foulbrood disease, J. Invertebr. Pathol. 67, 65-71.

SAS Institute Inc. (1997) SAS/STAT Software: changes and enhancements through release 6.12. SAS Institute, Inc., Cary, NC.

Shimanuki H. (1997) Bacteria, in: Morse R.A., Flottum K. (Eds.), Honey bee pests, predators \& diseases, A.I. Root Co., Medina, OH, pp. 33-54.

Shimanuki H., Knox D.A. (1994) Susceptibility of Bacillus larvae to Terramycin ${ }^{\circledR}$, Am. Bee J. 134, 125-126.

Spivak M., Gilliam M. (1998) Hygienic behaviour of honey bees and its application for control of brood diseases and varroa mites. Part I: Hygienic behaviour and resistance to American foulbrood, Bee World 79, 124-134.

Spivak M., Reuter G.S. (1998) Honey bee hygienic behavior, Am. Bee J. 138, 283-286.

Van Eaton C. (2000) American foulbrood and beekeeping sustainability, Bee Biz 12, 7-10. 